\title{
NATURAL RUBBER LATEX ALLERGY
}

H Alenius, K Turjanmaa, T Palosuo mmediate hypersensitivity to natural rubber latex (NRL) has become increasingly common during the last 20 years. It is currently one of the most frequently encountered occupational diseases among the healthcare workers and a problem even in other occupations where protective gloves are used.

Several groups at high risk for developing NRL allergy have been defined, including healthcare workers and children with spina bifida or other congenital malformations. However, the majority of NRL allergic patients do not belong to any of these groups but are individuals who usually have atopic background and are frequently in contact with NRL products. The wide spectrum of clinical manifestations of NRL allergy range from contact urticaria and rhinitis to severe systemic reactions-for example, asthma and anaphylaxis. Importantly also, NRL allergens become easily airborne with glove powder and may cause occupational asthma in individuals sensitised to NRL. In addition, a "latex fruit syndrome" has been described implying that, because of alleged allergen cross reactions, NRL allergic patients frequently show allergy to various fruits, such as banana, avocado, chestnut, and kiwi.

NRL, the raw material of natural rubber products, is obtained from the rubber tree Hevea brasiliensis. There is a consensus that proteins or peptides eluting from rubber products are responsible for sensitisation processes in NRL allergy. Knowledge of the causative allergens is required to develop reliable diagnosis of NRL allergy and to develop methods for determination of allergenicity of NRL products. At present, several important NRL allergens have been characterised at the molecular level, but knowledge about the allergens and their concentration in manufactured NRL products is still scanty.

\section{SYMPTOMS OF NRL ALLERGY}

The symptoms of immediate hypersensitivity to NRL can vary from mild local reactions to severe systemic reactions. The most frequently reported manifestation of NRL allergy is contact urticaria. Although skin is the most frequently reported site of allergic reactions, similar symptoms can be observed in mucous membranes as a result of oral, vaginal, and rectal exposure. However, it seems that systemic reactions-for example, angioedema and anaphylactic shock-are most frequently connected to exposure through mucous membranes. The majority of the cases have occurred during surgical, gynaecologic or obstetric procedures. Allergic rhinitis and asthma can occur after inhalation of NRL allergens. In addition to immediate type I allergy symptoms, NRL allergy can manifest on the hands of glove users as protein contact dermatitis or allergic contact dermatitis.

\section{FREQUENCY AND RISK GROUPS}

Based on several mainly Finnish studies the prevalence of latex allergy in the general population is less than $1 \% .{ }^{1}$ Higher prevalence numbers (up to 6.4\%) have been reported with serological tests in US and Italian blood donors, but the clinical histories of these persons could not be followed and therefore it is likely that a large proportion of such tests results are false positive.

Healthcare workers comprise the largest single risk group for the NRL allergy because of their frequent exposure to NRL products. In hospital employees the frequency of NRL allergy has varied from $2.8 \%$ to $17 \%$. In other occupations, where workers are regularly exposed to NRL gloves (greenhouse workers, housekeeping personnel, hairdressers and glove factory workers), frequency of NRL allergy has been reported to range from $5-11 \%$.

Children with spina bifida and other congenital anomalies requiring multiple surgical operations, and thereby frequent exposure to various latex devices, are at high risk of developing allergy to NRL. The frequency of NRL allergy in these children has ranged from 23-65\%. For some unknown reason, the NRL allergy frequencies in children with spina bifida have been lower in Europe than in the USA.

Atopy and hand eczema have been frequently associated with NRL allergy. Atopy in NRL allergic healthcare workers occurs 2.2 to 4.2 times more often than in workers with no NRL allergy. In NRL allergic adults the prevalence of hand eczema has been as high as $82 \%$. 


\section{Box 1 Main risk groups of NRL allergy}

Healthcare workers

- Children with spina bifida or other congenital anomalies and histories of multiple surgeries

- Atopic individuals

- People with hand dermatitis
Box 2 Recommended steps in the diagnosis of NRL

allergy

- Adequate clinical history

- Skin prick testing

- Specific lgE antibody tests (Immuno-CAP, AlaSTAT, etc.)

- Use or challenge tests to verify symptoms upon controlled exposure to NRL allergens

\section{Hev b 2 (1,3- $\beta$-glucanase)}

A $36 \mathrm{kD}$ protein, purified from NRL, showed high homology to several plant endo-1,3- $\beta$-glucanases in sequence analysis and bound IgE from $21 \%$ NRL allergic patient sera $(\mathrm{n}=29) .{ }^{4}$ Subsequently, Sunderasan et al isolated a basic-1,3- $\beta$-glucanase from Hevea latex and called it Hev b 2. ${ }^{5}$ Three Hev b 2 isoforms $(35 \mathrm{kD}, 36.6 \mathrm{kD}$, and $38 \mathrm{kD})$ were isolated from nonammoniated latex by Yagami et al. ${ }^{6}$ IgE antibodies to purified Hev b 2 were found in enzyme linked immunosorbent assay (ELISA) in $40 \%$ of the NRL allergic $(n=15)$ patients. These results indicate that $\mathrm{Hev} b 2$ is a significant NRL allergen.

serological tests for the diagnosis of NRL allergy: AlaSTAT (Diagnostic Products Corporation), Immuno-CAP (Pharmacia-UpJohn), and HY-TEC EIA (Hycor). In case of any discrepancy between symptoms and the skin prick test or specific IgE results a use (challenge) test is mandatory, but it should be kept in mind that serological tests are in general less sensitive than the skin prick test. However, use tests are not recommended for patients with a history of NRL related anaphylaxis when the skin prick test and/or specific IgE test are positive. A current problem is that no standardised use test material is available and gloves tend to become less allergenic, rendering them unsuitable as challenge material. The same is true for skin prick testing where certain high allergen gloves are used to provide suitable material for test eluates. However, one standardised skin prick test allergen preparation, which can safely be used, is commercially available (Stallergènes SA, France) in Europe.

\section{NRL ALLERGENS}

Of the more than 200 different proteins or polypeptides in NRL only about a quarter are allergens, meaning that sensitised individuals have formed IgE antibodies to them. Substantial progress has been made in recent years in the purification and molecular characterisation of NRL allergens, which has facilitated the assessment of their significance. The WHO/International Union of Immunological Societies Allergen Nomenclature Committee (www.allergen.org) now lists 11 NRL allergens characterised at the molecular level (table 1). Most of these allergens have been cloned and produced by recombinant DNA techniques. Linear B cell and T cell epitope analysis data have been reported for Hev b 1, Hev b 3, Hev b 5 , and Hev b 6. Three dimensional structure of hevein (Hev b 6.02 ) has been solved, rendering possible studies of conformational B cell epitopes.

\section{Hev b 1 (rubber elongation factor)}

Rubber elongation factor (Hev b l) was the first NRL allergen characterised at the molecular level. ${ }^{3}$ IgE antibodies to Hev b 1 have been common in patients with spina bifida or other congenital anomalies (60-80\%) while different authors have reported highly varying figures for adult NRL allergic patients (frequencies ranging from $0-100 \%$ ). Consensus exists that Hev b 1 is a major allergen in patients with SB although its significance in NRL allergic patients with no histories of multiple surgeries is still somewhat controversial.

\section{Hev b 3 (22-27-kD rubber particle protein)}

A $27 \mathrm{kD}$ NRL allergen associated with patients with spina bifida was first described in 1993 by Alenius et al. ${ }^{7}$ This allergen bound IgE from $83 \%$ of US and $67 \%$ of Finnish spina bifida patients and it showed partial sequence homology to Hev b 1 . Subsequently, $\mathrm{Lu}$ et $\mathrm{al}^{8}$ isolated from NRL a $23 \mathrm{kD}$ protein which revealed $45 \%$ similarity with $\mathrm{Hev}$ b $\mathrm{l}$ and shared iden$a l^{9}$ isolated a $24 \mathrm{kD}$ protein from small rubber particles that was similarly recognised by IgE from NRL allergic patients with spina bifida and was named as Hev b 3. Recently, a cDNA clone encoding a 204 amino acid NRL protein (22.3 kD; pI 4.6) and showing $47 \%$ identity to Hev b 1 was described. ${ }^{10}$ All published amino acid sequences of fragments of the $27 \mathrm{kD}$, the $23 \mathrm{kD}$, and the $24 \mathrm{kD}$ NRL allergens fit into the deduced amino acid sequence of the rHev b 3. In immunoblotting, 83\% of NRL allergic patients with spina bifida revealed IgE binding to $\mathrm{rHev}$ b 3 . These findings suggest that Hev b 3 is a highly important allergen for patients with spina bifida.

\section{Hev b 4 (50-57 kD microhelix protein complex)}

An acidic $50-57 \mathrm{kD}$ NRL protein that was bound by IgE in the serum from one NRL allergic patient was isolated and named as Hev b $4 .^{5} \mathrm{~N}$-terminal sequencing revealed no homology to any known sequences available in the data banks. Kurup et al described IgE responses to purified Hev b 4 by two different radioallergosorbent test (RAST) assays and by an ELISA method..$^{11}$ Depending on the IgE assay used, Hev b 4 was shown to bind IgE from $23-65 \%$ of the healthcare workers $(\mathrm{n}=31)$ and from $30-77 \%$ of the patients with spina bifida $(\mathrm{n}=13)$, suggesting that Hev b 4 is a major NRL allergen. However, in their study 6-20\% of the control subjects with no evidence of NRL allergy showed IgE binding to Hev b 4 . Further studies are needed to evaluate the role of $\mathrm{Hev} b 4$ as an NRL allergen.

\section{Hev b 5 (acidic NRL protein)}

Hev b 5 was cloned simultaneously by Slater et $a l^{12}$ and Akasawa et al. ${ }^{13} \mathrm{Hev}$ b 5 ( 163 aa) is one of the most acidic proteins in the laticifier cells of the rubber tree, and is exceptionally rich in glutamic acid. Hev b 5 shows high sequence homology (46\%) to kiwi fruit protein pKIWI501. In the study of Slater et al $56 \%$ of spina bifida patients $(\mathrm{n}=57)$ and $92 \%$ of tical sequence motifs with the $27 \mathrm{kD}$ protein. Later, Yeang et 
Table 1 NRL allergens

\begin{tabular}{lllll}
\hline Allergen & Trivial name & $\begin{array}{l}\text { Molecular } \\
\text { weight (kDa) }\end{array}$ & $\begin{array}{l}\text { Length } \\
\text { (amino } \\
\text { acids) }\end{array}$ & $\begin{array}{l}\text { Accession } \\
\text { number }\end{array}$ \\
\hline Hev b 1 & Rubber elongation factor & 14.6 & 138 & X56535 \\
Hev b 2 & Beta-1.3-glucanase & 35.1 & 374 & U22147 \\
Hev b 3 & Small rubber particle protein & 22.3 & 204 & A223388 \\
Hev b 4 & Microhelix complex & $50-57$ & NA & N/A \\
Hev b 5 & Acidic NRL protein & 16 & 151 & U42640 \\
& & & & U51631 \\
Hev b 6.01 & Prohevein & & 187 & M36986 \\
Hev b 6.02 & Mature hevein & 20 & 43 & \\
Hev b 6.03 & C-domain & 4.7 & 138 & \\
Hev b 7.01 & hom: patatin from B-serum & 14 & 388 & U80598 \\
Hev b 7.02 & hom: patatin from C-serum & 42.9 & 388 & AN223038 \\
Hev b 8 & Profilin & 42.9 & & A132397 \\
Hev b 9 & Enolase & & 131 & A132580 \\
Hev b 10 & Manganese superoxide dismutase & 22.9 & 206 & AN249148 \\
Hev b 1 1w & Class 1 chitinase & 30 & 295 & AN238579 \\
\hline NA, not available & & & & \\
\hline
\end{tabular}

healthcare workers $(n=13)$ with NRL allergy had IgE to Hev b 5. Similarly, IgE from more than $50 \%$ of adult NRL allergic patients reacted with Hev b 5 in the study by Akasawa et al. ${ }^{13}$ It is generally agreed that Hev b 5 is a highly significant allergen for both healthcare workers and patients with spina bifida.

\section{Hev b 6.01 (prohevein), Hev b 6.02 (hevein), and Hev b 6.03 (prohevein C-domain)}

Hevein is the predominant protein in NRL and has been suggested to be involved in the coagulation of rubber and protection of rubber tree wounds by inhibiting the growth of fungi. Hevein is synthesised as preproprotein ( 187 aa; also known as prohevein) that is processed into aminoterminal hevein (43 aa) and the carboxyterminal domain (138-aa C-domain). Hevein domain shows high homology to several chitin binding proteins in the plant kingdom, whereas the C-domain is highly homologous to wound inducible proteins.

Alenius et al reported that $69 \%$ of NRL allergic patients $(\mathrm{n}=56)$ had IgE antibodies to purified prohevein, whereas $21 \%$ of these patients had IgE against the purified prohevein C-domain. ${ }^{14}$ Moreover, 56\% of 45 NRL allergic patient sera showed IgE antibodies to purified N-terminal hevein domain. Essentially similar results were reported in the study of Banerjee et al where $84 \%$ of healthcare workers' sera $(n=25)$ exhibited IgE binding to recombinant prohevein. ${ }^{15}$ Recombinant hevein showed IgE binding with $88 \%$ sera whereas $40 \%$ of these patients had IgE to recombinant prohevein C-domain. In the study of Chen et al the skin prick test showed a positive reaction to purified hevein in $81 \%$ of patients $(n=21)$ with NRL allergy. ${ }^{16}$ All the available data indicate that prohevein and its $\mathrm{N}$-terminal hevein domain are major NRL allergens.

\section{Hev b 7 (patatin-like protein)}

Beezhold et al reported that IgE in sera from $22 \%$ of NRL allergic patients $(\mathrm{n}=29)$ is bound to a $46 \mathrm{kD}$ NRL protein. ${ }^{17}$ This protein was later cloned, called Hev b 7, and shown to have $39-42 \%$ homology with patatin from potato. More recently, Kurup et al measured IgE responses to purified Hev b 7 by different assays (two RAST assays and an ELISA) and found that, depending on the method used, $15-77 \%$ of the NRL allergic patients including healthcare workers and spina bifida patients demonstrated IgE antibodies to purified Hev b 7. ${ }^{18}$ The overall significance of Hev b 7 and its possible isoforms (table 1) remain to be assessed.

\section{Hev b 8 (profilin)}

Profilins, ubiquitously present in various plants, are frequently identified as IgE binding proteins. Vallier et al showed that NRL profilin (Hev b 8) bound IgE in sera from 2/19 (11\%) NRL allergic patients. ${ }^{19}$ A more recent study by Rihs et al using recombinant Hev b 8 as an antigen found 5/25 (20\%) NRL allergic patient sera with IgE antibodies to profilin. ${ }^{20} \mathrm{Hev}$ b 8 appears to represent a minor NRL allergen.

\section{Hev b 9 (enolase)}

Recently, the cloning of a 1651 bp cDNA encoding a protein of 445 amino acids (47.6 kD; pI 5.6) from Hevea latex was described. ${ }^{21}$ The Hev b 9 displays $62 \%$ identity with Cla h 6, the enolase of the mould Cladosporium herbarum, and $60 \%$ identity with Alt a 5, the enolase of the Alternaria alternata. Sixteen out of 110 NRL allergic patients (14.5\%) showed IgE binding to rHev b 9, suggesting that Hev b 9 is a minor NRL allergen.

\section{Hev b 10 (manganese superoxide dismutase: MnSOD)}

A Hevea latex MnSOD consisting of 206 amino acid residues was cloned and expressed in Escherichia coli. ${ }^{22}$ The allergen was designated as Hev b 10. In immunoblotting, NRL as well as Aspergillus fumigatus allergic patients revealed IgE binding to rHev b 10. Cross reactivity to Asp f 6, the MnSOD from A fumigatus, and human MnSOD was determined by inhibition of IgE binding to these MnSODs by rHev b 10 . Hev b 10 is a new cross reactive allergen of $H$ brasiliensis which belongs to the "latex mould" group of latex allergens.

\section{Hev b 11 w (class 1 chitinase)}

Cloning and expression of a class I chitinase (295 aa) from Hevea latex has been reported in the list of the Allergen Nomenclature Committee by O'Riordain et al. ${ }^{23}$ However, no information on IgE binding abilities of the protein is available at present.

\section{IGE BINDING EPITOPES OF NRL ALLERGENS}

Knowledge of IgE binding structures on the surface of allergen is important when designing tools and strategies for allergen specific immunotherapy. Recently linear IgE binding epitopes of several NRL allergens have been described. 


\section{Box 3 Major NRL allergens}

- Adult patients

- Hev b 6.01

- Hev b 6.02

- Hev b 5

- Hev b 2 (?)

Children with spina bifida

- Hev b 1

- Hev b 3

IgE binding sites on Hev b l have been analysed by ELISA using synthetic overlapping peptides covering the whole Hev b 1 sequence. ${ }^{16} \mathrm{IgE}$ binding epitopes were located in C-terminal segment (121-137) and the segments with amino acid residues of 30-49 and 46-64. Banerjee et al synthesised overlapping decapeptides of prohevein ( $\mathrm{Hev} \mathrm{b} 6.01$ ) on cellulose membrane. ${ }^{15}$ Two major linear IgE binding epitopes (aa 19-24 and 25-37) were detected in the $\mathrm{N}$-terminal hevein domain (Hev b 6.02) and three epitopes in the C-domain (Hev b 6.03) (aa 60-66, 98-103, 164-172). Essentially similar results were reported by Beezhold et al who identified by synthetic overlapping epitope mapping in prohevein altogether 6 IgE epitopes, two in the hevein domain and four in the C-domain. ${ }^{24}$ Beezhold et al synthesised octapeptides spanning the entire Hev b 5 protein and detected six IgE binding regions located throughout the molecule (aa 15-22, 28-32, 50-56, 76-81, 90-95, and 132-139). ${ }^{25}$ Investigation of linear IgE binding regions of the two homologous NRL allergens, Hev b 1 and Hev b 3, have been recently described. ${ }^{26}$ The authors found eight IgE binding epitopes for Hev b 1 and 11 for Hev b 3, identified by sera from NRL allergic patients with spina bifida. In competitive ELISA, combination of two Hev b l peptides inhibited $58 \%$ of IgE binding of Hev b l, while a combination of two Hev b 3 peptides inhibited $22 \%$ of IgE binding to Hev b 3.

A combination of linear peptide mapping strategy and mutational IgE analysis was recently used in the study by Beezhold et al. ${ }^{27}$ Eleven epitopes were identified in Hev b 5 by SPOTs analysis. Alanine substitutions to synthetic peptides were used to identify the important amino acids for IgE binding. Site directed mutagenesis was used to replace the crucial amino acids with alanine in a recombinant Hev b5 mutant. Twenty clones with different combinations of altered epitopes were evaluated by means of IgE inhibition assays. Clones with mutations in single epitopes failed to reduce IgE binding, but simultaneous changes into eight epitopes (simultaneous mutation of 14 selected amino acids) resulted in a 4500-fold reduction in IgE binding. Mutants with reduced IgE binding activity may prove to be valuable reagents for immunotherapy.

A novel approach to the localisation and reconstruction of conformational IgE binding epitope regions of hevein (Hev b 6.02 ), has been recently described by Karisola et al. ${ }^{28}$ An antimicrobial protein (AMP) from the amaranth, Amaranthus caudatus, was used as an immunologically silent adaptor molecule to which terminal or central parts of hevein were fused. Hevein and AMP share a structurally identical core region, but have different $\mathrm{N}$-terminal and $\mathrm{C}$-terminal regions. Only 1/16 hevein allergic patients showed weak IgE binding to purified AMP. Chimeric AMP with the hevein N-terminus (aa $1-11$ ) was recognised by IgE from $14(88 \%)$ patients and the AMP chimera with the hevein C-terminus (aa $32-43$ ) by six (38\%) of the patients. When both the N-terminal and C-terminal

\section{Box $4 \mathrm{~T}$ and B cell epitopes}

- B cell epitope: the part of the surface on an antigen/allergen that interacts with the Fab fragment of the corresponding antibody

- Most, if not all, B cell epitopes are conformational, recognised by their three dimensional structures

- T cell epitopes, recognised by specific T cells, are short linear peptides

regions of hevein were fused with the AMP core, IgE from all 16 patients bound to the chimera. In contrast, only two patients showed IgE to the AMP chimera containing hevein core region (aa 12-31). These results suggest that the IgE binding ability of hevein is almost exclusively determined by its $\mathrm{N}$-terminal and C-terminal regions, which seem to contain conformational epitopes not detectable by linear IgE epitope analysis. The chimera based epitope mapping strategy may provide a valuable tool for defining structural epitopes and selecting critical amino acids for site directed mutagenesis.

\section{ALLERGENS IN NRL PRODUCTS}

It is known that both the protein and allergen content can vary considerably in NRL gloves. Twenty to 100 -fold differences have been demonstrated in protein concentrations, and 3000 -fold differences in the allergen contents, of various NRL glove brands. ${ }^{29}$ Several studies have indicated that the total protein content measured by the modified Lowry method correlates relatively well with the true allergen content measured by the skin prick test or human IgE based immunologic inhibition assays. Yet, discrepant findings are not uncommon: some NRL glove brands have been described with rather high total protein content, but with low NRL allergen concentration, and vice versa. Other proteins, such as casein, may also be added to the NRL during glove manufacture which then can increase the total protein content of the glove. Therefore, consensus exists that at the level of individual gloves, protein concentration is not sufficient to draw conclusions on the safety of NRL gloves.

Knowledge about the presence of the specific NRL allergens in the NRL gloves and other manufactured rubber products is rapidly increasing but still scanty. Hev b l was first extracted from NRL gloves. ${ }^{3}$ Large amounts of immunologically active Hev b 6.02 have previously been purified from a highly allergenic glove brand. ${ }^{14}$ Recently, a two site monoclonal antibody based assay has been developed to measure $\mathrm{Hev}$ b l concentrations in NRL products. ${ }^{30}$ In a study with five different brands of NRL gloves, Hev b l concentrations were found to be in the range of $18-40 \mu \mathrm{g} / \mathrm{g}$ of rubber material, corresponding to $2-4 \%$ of the total extractable protein content in NRL glove extracts. Similarly, a capture ELISA for the measurement of Hev b 6.02 and Hev b 5, using recombinant or purified natural allergens and monoclonal and/or polyclonal antibodies, has been developed..$^{31}$ In 20 NRL gloves, marketed in Finland and worldwide in 1999, Hev b 6.02 and Hev b 5 were detected in all gloves showing NRL allergen activity by a skin prick test validated human IgE based ELISA method. The specific allergen content and total allergen activity correlated in a highly significant manner. In quantitative terms the concentrations of Hev b 6.02 were 2-10-fold higher than those of Hev b 5. It is likely that Hev b 6.02 and Hev b 5 are responsible of a major part of latex allergen concentrations in currently marketed medical gloves. Similarly, Yeang et al quantified Hev b 2 and 
Box 5 "Latex fruit syndrome"

- Concomitant allergies most frequently to:

- banana

- avocado

- chestnut

- kiwi fruit

Hev b 3 concentrations in five brands of NRL gloves by a two site ELISA employing a monoclonal antibody and a biotinylated polyclonal antibody, and showed that both Hev b 2 and Hev b 3 could be detected from the gloves.

\section{LATEX ALLERGEN CROSS REACTIVITY}

Patients with NRL allergy are mostly atopic subjects who frequently show positive skin prick tests to various foods of plant origin. Blanco et al reported immediate food hypersensitivities in $52 \%$ of 25 NRL allergic adult patients. ${ }^{32}$ More than a half of these patients had experienced serious systemic reactions from the foods. The most common allergies verified by clinical history and skin prick tests were to avocado (36\%), chestnut (36\%), banana (28\%), kiwi fruit (20\%), and papaya ( $12 \%)$. The authors introduced the term "latex fruit syndrome" for the simultaneous occurrence of allergic reactions to NRL and various fruits. Beezhold et al examined the frequency of food allergies in $47 \mathrm{NRL}$ allergic health care workers and reported that $70 \%$ had a positive skin prick test to at least one food..$^{33}$ The frequencies were $53 \%$ to avocado, $40 \%$ to potato, $38 \%$ to banana, $28 \%$ to tomato and chestnut, and $17 \%$ to kiwi fruit. At present, it seems that allergic reactions to avocado, banana, kiwi fruit, and chestnut are the most frequently reported food sensitivities in the adult NRL allergic patients.

A large number of studies have recently been addressed to clarify the molecular basis of these cross reactions. At present, there is much evidence that at least a part of the cross reactivity between NRL and various fruits is based on structural homology between hevein and hevein-like domains of plant class I chitinases. Besides that, only little is known.

\section{PREVENTION AND MANAGEMENT OF NRL ALLERGY}

There is no specific treatment for NRL allergy, except total avoidance of materials containing NRL. However, this goal is almost impossible to achieve since a wide variety of medical and household products contain NRL. Substantial reductions in NRL allergen exposure may be achieved by the use of low allergen NRL gloves ${ }^{34}$; eliminating powdered gloves ${ }^{35}$ has also been reported to lower exposure to NRL allergens.

Because avoidance of NRL products can be difficult, immunotherapy with well characterised and potent mixtures of relevant allergens would be a potential option. In a preliminary

\section{Box 6 Future prospects in studies of NRL allergy}

- Future studies are likely to be focused on immunodominant and cross reactive $T$ cell and $B$ cell epitopes and on ways to modify or destroy allergenic B cell epitopes

- Better diagnostic reagents and tools for immunotherapy, using purified or recombinant and mutated allergens, will be developed

- New knowledge on NRL allergens will eventually help rubber manufacturers to develop less allergenic products and allow regulatory authorities to introduce acceptable limits for specific allergens in NRL products

\section{Box 7 Natural rubber latex (NRL) allergy: key points}

- The prevalence of NRL allergy in the general population is about $1 \%$, but NRL allergy is a major occupational problem, especially in health care

- The major risk groups are healthcare workers and people using protective NRL gloves, atopic subjects in general, and children with spina bifida or other congenital malformations

- Patients with NRL allergy frequently have concomitant allergies to various fruits and foods, a large proportion of which are believed to be caused by allergen cross reactivity

- Several NRL allergens have been characterised-the most important ones are Hev b 5 and Hev b 6 for adults, and Hev b 1 and Hev b 3 for children with spina bifida

- Methods to measure specific allergen contents of various NRL products, instead of total protein, are becoming available

study Toci et al reported oral latex desensitisation with ammoniated latex in three healthcare workers who had severe clinical latex allergy. ${ }^{36}$ After desensitisation all three patients were able to return to their work which involved heavy NRL exposure. Similarly, Pereira et al treated a highly allergic radiology technician with ammoniated latex. ${ }^{37}$ After NRL immunotherapy clinical symptoms improved steadily and the individual returned to work in an environment with significant latex exposure.

\section{FUTURE PROSPECTS}

Knowledge of the whole spectrum of NRL allergens will help researchers to develop more specific in vivo and in vitro tests for diagnostic purposes and the production of pure allergens could provide tools for immunotherapy. Future studies will undoubtedly be focused on the analysis of immunodominant IgE epitopes in the allergen molecules and in possibilities to modify or destroy them to decrease their allergenic potential. For the moment there are already preliminary reports of latex specific immunotherapy with promising results.

Recent research has brought specific methods for quantifying NRL allergens in medical and other gloves, and this progress has already led governmental authorities in certain countries to inform the consumers on the highly allergenic glove brands in the market. The international rubber manufacturers could also benefit from these new methods which are expected to help the development of less allergenic gloves and other NRL products.

\section{Authors' affiliations}

H Alenius, Finnish Institute of Occupational Health, Helsinki, Finland K Turjanmaa, Department of Dermatology, Tampere University Hospital and University of Tampere, Tampere, Finland

T Palosuo, National Public Health Institute, Helsinki, Finland

\section{REFERENCES}

1 Liss GM, Sussman GL. Latex sensitization: occupational versus general population prevalence rates. Am J Ind Med 1999;35:196-200.

- This report provides a comprehensive overview of prevalence studies of NRL allergy conducted among occupationally exposed and general population groups.

2 Turianmaa K, Alenius H, Makinen-Kiljunen S, et al. Natural rubber latex allergy. Allergy 1996;51:593-602.

3 Czuppon AB, Chen Z, Rennert S, et al. The rubber elongation factor of rubber trees (Hevea brasiliensis) is the major allergen in latex. J Allergy Clin Immunol 1993;92:690-7.

- This study describes the original work related to identification, purification, and molecular characterisation of the Hev b 1, a major allergen in children with spina bifida. 
4 Alenius $\mathbf{H}$, Kalkkinen N, Lukka $M$, et al. Prohevein from the rubber tree (Hevea brasiliensis) is a major latex allergen. Clin Exp Allergy 1995;25:659-65.

- This article describes for the first time purification and molecular characterisation of two important NRL allergens, Hev b 6.01 and Hev b 2.

5 Sunderasan E, Hamzah S, Hamid S, et al. Latex B-serum b-1,3-glucanase (Hev b II) and a component of the microhelix (Hev b IV) are major latex allergens. J Nat Rubb Res 1995;10:82-99.

4246 Yagami T, Sato M, Nakamura A, et al. Plant defense-related enzymes as latex antigens. J Allergy Clin Immunol 1998;101:379-85.

7 Alenius $H$, Palosuo T, Kelly K, et al. IgE reactivity to $14-\mathrm{kD}$ and $27-\mathrm{kD}$ natural rubber proteins in latex-allergic children with spina bifida and other congenital anomalies. Int Arch Allergy Immunol 1993;102:61-6.

8 Lu LJ, Kurup VP, Hoffman DR, et al. Characterization of a major latex allergen associated with hypersensitivity in spina bifida patients. J Immunol $1995 ; 155: 2721-8$.

9 Yeang H, Lau C, Arija S, et al. Hev b 2 and Hev b 3 content in natural rubber latex and latex gloves. J Allergy Clin Immunol 2001;107:S1 18

10 Wagner B, Krebitz M, Buck D, et al. Cloning, expression, and characterization of recombinant Hev b 3 , a Hevea brasiliensis protein associated with latex allergy in patients with spina bifida. J Allergy Clin Immunol 1999;104:1084-92.

- In this paper the role of Hev b 3, a major NRL allergen for patients with spina bifida, is confirmed and its molecular structure is clarified.

11 Kurup VP, Yeang HY, Sussman GL, et al. Detection of immunoglobulin antibodies in the sera of patients using purified latex allergens. Clin Exp Allergy 2000;30:359-69.

12 Slater JE, Vedvick T, Arthur-Smith A, et al. Identification, cloning, and sequence of a major allergen (Hev b 5) from natural rubber latex (Hevea brasiliensis). J Biol Chem 1996;271:25394-9.

- This paper, together with reference 13, describes cloning of a novel highly significant NRL allergen.

13 Akasawa A, Hsieh LS, Martin BM, et al. A novel acidic allergen, Hev b 5, in latex. Purification, cloning and characterization. J Biol Chem 1996;271:25389-93.

- In addition to reference 12, this paper demonstrates that significant amounts of Hev b 5 can be detected in NRL gloves.

14 Alenius H, Kalkkinen N, Reunala T, et al. The main lgE-binding epitope of a major latex allergen, prohevein, is present in its $\mathrm{N}$-terminal 43-amino acid fragment, hevein. J Immunol 1996;156:1618-25.

- This paper demonstrates that prohevein (Hev b 6.01) and its $\mathrm{N}$-terminal hevein domain (Hev b 6.02) are major NRL allergens. In addition, it shows that large amounts of hevein can be extracted from NRL gloves.

15 Banerjee B, Wang X, Kelly KJ, et al. IgE from latex-allergic patients binds to cloned and expressed B cell epitopes of prohevein. J Immunol 1997; 159:5724-32

16 Chen Z, Van Kampen V, Raulf-Heimsoth $M$, et al. Allergenic and antigenic determinants of latex allergen Hev b 1: peptide mapping of epitopes recognized by human, murine and rabbit antibodies. Clin Exp Allergy 1996;26:406-15.

17 Beezhold DH, Sussman GL, Kostyal DA, et al. Identification of a 46-kD latex protein allergen in health care workers. Clin Exp Immunol 1994;98:408-13

18 Kurup VP, Fink JN. The spectrum of immunologic sensitization in latex allergy. Allergy 2001;56:2-12.

19 Vallier P, Balland S, Harf R, et al. Identification of profilin as an lgE-binding component in latex from Hevea brasiliensis: clinical implications. Clin Exp Allergy 1995;25:332-9.

20 Rihs HP, Chen Z, Rozynek P, et al. PCR-based cloning, isolation, and lgE-binding properties of recombinant latex profilin ( $\mathrm{rHev} \mathrm{b} 8$ ). Allergy 2000;55:712-7.
21 Wagner S, Breiteneder H, Simon-Nobbe B, et al. Hev b 9, an enolase and a new cross-reactive allergen from hevea latex and molds. Purification, characterization, cloning and expression. Eur J Biochem 2000;267:7006-14

22 Wagner S, Sowka S, Mayer C, et al. Identification of a Hevea brasiliensis latex manganese superoxide dismutase $(\mathrm{Hev} b \mathrm{10})$ as a cross-reactive allergen. Int Arch Allergy Immunol 2001;125:120-7.

23 O'Riordain G, Godnic-Cvar J, Radaver C, et al. Cloning and expression of a class I chitinase from latex, Hevea brasiliens. Accession number AJ238579; reported in the list of the Allergen Nomenclature Subcommittee; www.allergen.org

24 Beezhold DH, Kostyal DA, Sussman GL. IgE epitope analysis of the hevein preprotein; a major latex allergen. Clin Exp Immunol 1997; 108:114-21.

25 Beezhold DH, Hickey VL, Slater JE, et al. Human lgE-binding epitopes of the latex allergen Hev b 5. J Allergy Clin Immunol 1999;103:1 166-72.

26 Banerjee B, Kanitpong K, Fink JN, et al. Unique and shared lgE epitopes of $\mathrm{Hev} \mathrm{b} 1$ and Hev b 3 in latex allergy. Mol Immunol 2000;37:789-98.

27 Beezhold DH, Hickey VL, Sussman GL. Mutational analysis of the lgE epitopes in the latex allergen Hev b 5. J Allergy Clin Immunol 2001;107: 1069-76.

28 Karisola $\mathbf{P}$, Mikkola J, Alenius $\mathrm{H}$, et al. Specific lgE-binding epitopes of hevein can be reconstructed to an immunologically nonreactive antimicrobial protein (AMP) from Amaranthus Caudatus. J Allergy Clin Immunol 2001;107:S114.

29 Yunginger JW, Jones RT, Fransway AF, et al. Extractable latex allergens and proteins in disposable medical gloves and other rubber products. $J$ Allergy Clin Immunol 1994;93:836-42.

- This paper describes for the first time measurement and high variation of allergen content in NRL gloves.

30 Raulf-Heimsoth M, Sander I, Chen Z, et al. Development of a monoclonal antibody-based sandwich ELISA for detection of the latex allergen Hev b 1. Int Arch Allergy Immunol 2000;1 23:236-41.

31 Palosuo T, Ovod V, Kärkkäinen T, et al. The major latex allergens Hev b6.02 (hevein) and Hev b 5 are regularly detected in medical gloves with moderate or high allergen content. J Allergy Clin Immunol 2001;107:S321

32 Blanco C, Carrillo T, Castillo R, et al. Latex allergy: clinical features and cross-reactivity with fruits. Ann Allergy 1994;73:309-14.

- This paper highlights the common occurrence of "latex fruit syndrome".

33 Beezhold DH, Sussman GL, Liss GM, et al. Latex allergy can induce clinical reactions to specific foods. Clin Exp Allergy 1996;26:416-22.

34 Turianmaa K, Kanto M, Kautiainen $\mathrm{H}$, et al. Long-term outcome of 160 adult patients with natural rubber latex allergy. J Allergy Clin Immunol (in press).

35 Allmers H, Brehler R, Chen Z, et al. Reduction of latex aeroallergens and latex-specific lgE antibodies in sensitized workers after removal of powdered natural rubber latex gloves in a hospital. J Allergy Clin Immunol 1998:102:841-6.

36 Toci G, Shah s, Al-Faquih A, et al. Oral latex desensitization of healthcare workers. J Allergy Clin Immunol 1998;101:S161.

37 Pereira C, Rico P, Lourenco $M$, et al. Specific immunotherapy for occupational latex allergy. Allergy 1999;54:291-3.

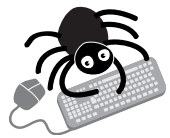

Additional references appear on the Occupational and Environmental Medicine website-www.occenvmed.com 